\title{
CONDITIONS FOR SAFE UNDERGROUND GASIFICATION OF LIGNITE IN POLAND
}

Particular attention was paid to geotechnical problems encountered during lignite mining in Polish deposit conditions. Geotechnical protection of safe lignite utilization by its gasification involves many issues such as presence of underground water, predicted land subsidence and deformation, etc. Great importance is attached to surface facilities and buildings safety and to protection of urban areas.

УМОВИ ДЛЯ БЕЗПЕЧНОЇ ПІДЗЕМНОЇ ГАЗИФІКАЦІЇ ПРИ ВИДОБУТКУ БУРОГО ВУГІЛЛЯ У ПОЛЬЩІ

Особлива увага приділялася геотехнічним проблемам, з якими стикаються при видобутку бурового вугілля в Польщі. При геотехнічному захисті безпечного видобутку бурого вугілля за допомогою газифікації виникає багато проблем, таких як: наявність підземних вод, просідання земної поверхні, деформація і т.д. Величезне значення приділяється наземним спорудам, їх безпеці та охороні міських районів.

УСЛОВИЯ ДЛЯ БЕЗОПАСНОЙ ПОДЗЕМНОЙ ГАЗИФИКАЦИИ ПРИ ДОБЫЧЕ БУРОГО УГЛЯ В ПОЛЬШЕ

Особое внимание уделялось геотехническим проблемам, с которыми сталкиваются при добыче бурового угля в Польше. При геотехнической защите безопасной добычи бурого угля с помощью газификации возникает много проблем, таких как: наличие подземных вод, проседание земной поверхности, деформация и т.д. Огромное значение уделяется наземным сооружениям, их безопасности и охране городских районов.

\section{INTRODUCTION}

Methods of lignite utilization by its gasification have been known for a long time and have been successfully applied during last decades, especially the underground gasification. Most of output in this method development comes from numerous studies and applications carried out in former Soviet Union countries. Those achievements were implemented in dynamic development of many countries.

Currently the research studies on using the underground gasification of lignite are carried out in Poland funded by the science grants but also by KGHM Polska Miedź SA. The dominating opinion in the company says that the word experience should be utilized in order to shorten the research period before implementation of commercial installations. In light of previous technological achievements such approach will substantially accelerate the possibility of practical application of underground gasification of lignite (PZWB).

One of the barrier, in implementing this method, is a way of reporting the lignite resources and legal procedure while applying for exploration and mining concession. Stand- 
ing regulations concerning the above issues is very favorable for the open pit mining methods. According to these regulations, underground gasification of lignite is regarded as lignite mining through unconventional method.

\section{GEOLOGY OF LIGNITE DEPOSIT AREAS IN RESPECT OF PZWB IMPLEMENTATION}

Geology of lignite deposit areas in Poland is very complex. The lignite beds are usually horizontal or with little inclination but also a disturbed beds are encountered. Thus the techniques of underground gasification specific for horizontal beds will dominate. They are much more difficult in practice than the ones applied in case of deposits having big inclination.

The lignite may have a form of many beds or one very thick bed, for example $35 \mathrm{~m}$ ore more, but also it may be divided into several layers. Typical is high humidity of lignite beds, reaching $40-50 \%$, what in turn causes problems with dewatering and dosing the vapor necessary in gasification process. Moreover, in the overburden multi-layer complex systems of different soils such as: sands, clays, muds, aggregates i.e. mostly crushed formations, occur. Very often the over-lignite beds are aquifers, what is a great challenge while draining them and preparing the operation of underground gas generators. Complex structure of the overburden requires such location of gas generators to have the impermeable soils within the zone of continuous deformations, therefore at the proper distance over the high temperature sectors. It is aimed to protect the tight bed from the thermal impact and the structural changes. If it is impossible, the additional engineering methods of sealing the zones over the gas generators should be used.

Separate and very important issue is a protection of surface and underground water reservoirs. Since the researches show attenuation of contamination 30 meters from its source, it is deemed that minimal distance from the reservoir should be $40 \mathrm{~m}$. Utilization of such 10 $\mathrm{m}$ long safety zone is, however, not always sufficient. Additional analyze of geological and water conditions of the deposit area where gasification is planned becomes necessary. In such cases model studies using advanced software, basing on finite elements method, are the most justified.
HYDROGELOGICAL CONDITIONS

\begin{tabular}{|l|l|}
\hline $\begin{array}{l}\text { Utility aquifers and main under- } \\
\text { ground water reservoirs }\end{array}$ & $\begin{array}{l}\text { Beds occurring below utility aquifers (minimal distance } 40 \mathrm{~m} \text { ), ab- } \\
\text { sence of main underground water reservoirs in close vicinity of pro- } \\
\text { spective extraction field (minimal distance }-2 \mathrm{~km} \text { ) }\end{array}$ \\
\hline Porosity of surrounding rocks & $\begin{array}{l}\text { Rocks above and below the deposit sholud have smaller gas perme- } \\
\text { ability than the lignite bed, Thickness of rock with low permeability } \\
\text { surrounding the lignite bed should be 1-2 } \mathrm{m} \text { for } 2 \mathrm{~m} \text { thick lignite } \\
\text { bed or 2-4 m for 3-10 m lignite bed }\end{array}$ \\
\hline Water inflow & $\begin{array}{l}\text { Maximum volume of water necessary gas production is } 0.5 \text { ton per } \\
1 \text { ton of gasified lignite, water surplus should be pumped out }\end{array}$ \\
\hline Filtration properties of rocks & $\begin{array}{l}\text { Lignite bed porosity vs. surrounding rock porosity should not be } \\
\text { smaller than 18:20 }\end{array}$ \\
\hline
\end{tabular}

One of the crucial issue while using PZWB method is protection against excessive subsidence, especially of non-continuous nature. In many countries using PZW installations, the surface subsidence problem is of smaller importance due to location of the site where the extraction is carried out or because of specific outcrop structure. It may be a depopulated land or located on mining area, where extraction using other methods takes 
place or the overburden is formed of soft rocks. However, in Poland the population is high, the surface infrastructure is complex: roads, numerous buildings, railways, power supply lines etc. In such situation the land subsidence is not acceptable.

The overburden occurring over the lignite deposit is formed of loose soil beds. These are sands of different granulation, often water saturated, clays, silts, muds and others. Layers of such soil are often interrupted, have numerous lens and admixtures and structural discontinuities. Under such conditions, subsidence is integral process accompanying this type of extraction. In case of PZW the subsidence is bigger because the over lying soils are the subject of additional deformations resulting from thermo-consolidation processes i.e. changes of humidity, swelling and shrinking, cracking and uncontrolled water flows.

\section{SUSTAINABLE DEVELOPMENT AND PZWB METHOD}

Objective with regard of sustainable development is an effort to maintain the balanced relations between technical progress, environmental protection and economic development. PZW method is relatively cheap, however, in case of adverse deposit parameters costs of its application increase. Also protecting the environment from its negative impact may be expensive. In this instance the location of deposit is of vital importance, Table 2.

SITE CONDITIONS FOR PZW INSTALLATION

Table 2

\begin{tabular}{|l|l|}
\hline $\begin{array}{l}\text { Area required for PZW } \\
\text { installation }\end{array}$ & $\begin{array}{l}\text { minimal area for pilot installation is } 50-100 \mathrm{ha}\left(0.5-1 \mathrm{~km}^{2}\right), \text { for commercial } \\
\text { installation over } 100 \mathrm{ha} \text {, changing location }\end{array}$ \\
\hline Safety conditions & $\begin{array}{l}\text { Minimal distance from: residential areas }(1-3 \mathrm{~km}) \text {, rivers and lakes } \\
(1-3 \mathrm{~km}), \text { protection areas }(5 \mathrm{~km}), \text { operating mines } / \text { mining areas } \\
(5 \mathrm{~km}), \text { closed mines/workings }(3 \mathrm{~km}), \text { power lines and railroads }(1-3 \mathrm{~km})\end{array}$ \\
\hline Legal conditions & $\begin{array}{l}\text { Preparing the opinion on environmental impact, identifying land property, } \\
\text { getting concession for deposit exploration, geological study concerning prob- } \\
\text { able mineral reserves, public consultation, delimitation of mining area and } \\
\text { getting concession for deposit extraction, buying the land }\end{array}$ \\
\hline
\end{tabular}

When planning the location of area for underground gasification, the critical elements of infrastructure and environment, present over the deposit, must be taken into consideration. Among these elements are: land development (buildings, telecom and power lines, gas mains, roads, railroads), level of land use, distance from old mine workings and operating conventional mines, environmental conditions (soils, forests, protection areas, lakes, rivers). All those factors may be decisive with regard of possibility of using the method in agreement with environment and community development.

Currently high capacity installations for underground gasification are widely used. However, they are not suitable for very big deposits, which, when mined using open pit method, give 20-30 million tons per year during many years. Conventional method does not need also great volumes of backfilling material preventing the subsidence. While the PZW method does not guarantee the development of whole big deposit but only a part of it, due to the demand for huge amount of backfilling material.

In such case constructing many smaller installations spread over the big area seems to be reasonable. It is important to diversify the energy sources and to limit the power loses on big transmission lines.

Underground gasification systems give the wide range of products with different application such as energetic gas, heat, power energy, liquid fuels (oil and gas) and numerous valuable but less commonly used products. For 
first Polish implementations the most reasonable is production of energetic gas, power energy and heat energy manufactured in the cogeneration systems.

\section{GEOTECHNICAL PROTECTION IN PZWB METHOD IMPLEMENTATION}

Like in every mine, the geotechnical issues are extremely important in case of underground lignite gasification. They decide about the possibility of using this method. Geotechnical processes occurring during the lignite mining from Polish deposits concern many elements of their development. Geotechnical protection aimed to assure the safe utilization of lignite reserves using this method refers to underground water, predicted land subsidence and deformations, mining system and environmental protection.

When PZW method is used, the effective drainage of the part of lignite deposit destined for gasification is of great importance. In some cases not only drainage will be necessary but also silting-up the extremely permeable aquifers. It may be necessary to maintain the water inflow on the level enabling the proper gasification process. Otherwise the syngas parameters will be on inadequate level.

Under Polish conditions extremely important is backfilling the voids formed as a result of gasification. The geological structure and processes occurring inside the overburden layers show that these voids will be formed generally in the lignite bed and inside the overburden. It is a result of roof collapse due to the stability loss. The overburden falling into the voids and solid products of gasification are porous. Blow gases flow well through the empty spaces despite the rubble formation, and at the same time the loosen overburden and empty rooms shift upwards. In such case the backfilling may be held even in the over lignite zone. It requires the proper identification of room location in order to fill it with backfilling material as fully as possible. Both hydraulic and pneumatic methods may be used there. When the beds are thicker and there are several gas generators (lignite beds) caving results in adding the post-reaction voids what in turn allow for better filling them. Thus the backfilling effectiveness is better.

Further subsidence protection may be achieved by using the proper organization of mining operations. Gasification may be carried out along the line courses, leaving the temporary, safety pillars between them. After gasification of lignite along two lines and backfilling them, the gasification of pillar between two lines can be started. Such organization of mining effectively prevents the subsidence and at the same time allows for efficient utilization of deposit as well as reduction of loses.

Using adequate and properly selected geotechnical solutions is a condition for correct operation of the installation and protection against adverse impact on the environment.

\section{CONDITIONS FOR IMPLEMENTING THE METHOD IN POLAND}

The basis during implementation of PZW method and constructing the installation for underground gasification are the project assumptions which describe the function, power and period of enterprise in details and thereby specify the minimal level of lignite reserves. When it is planned to extend the project it is necessary to provide the possibility of mining further mining fields.

Planned installations for underground gasification must meet the requirements of:

- Geological and mining law;

- Power energy law;

- Environmental protection law;

- Building law;

- Land development plan.

Consistency with above legal document impose many, difficult to meet, conditions, which implementation may continue over even several years.

The possibility of using underground lignite gasification in Poland meets with big public expectations. It mostly results from the belief that this method can totally replace open pit mining, widely used now. Disadvantage of the latter, in public opinion, is the deg- 
radation of environment. Most often it is caused by shortage of knowledge, among local community, about proper procedure of carrying out mining activity and about its effects. There is also lack of common knowledge concerning the legal requirements with regard of planning and monitoring such projects. Before launching any project the vide information campaign should be carried out among local population about safety issues concerning social and environmental aspects of the investment.

SPECIFICATION OF QUALIFICATION CRITERIA FOR LIGNITE BEDS DESTINED

Table 3

FOR UNDERGROUND GASIFICATION

\begin{tabular}{|l|l|}
\hline \multicolumn{1}{|c|}{ Qualification criterion } & \multicolumn{1}{c|}{ Characteristics } \\
\hline Type of lignite & xylite, xylite-earthy, earthy, bituminous \\
\hline $\begin{array}{l}\text { Physical \& chemical properties of lignite critical } \\
\text { for gasification process }\end{array}$ & $\begin{array}{l}\text { Preferred lignite with ash content below 20\%, and } \\
\text { low sulphur content }\end{array}$ \\
\hline Thickness of lignite bed & More than $2 \mathrm{~m}$, optimal - $4 \mathrm{~m}$ and more \\
\hline Depth of lignite bed & Recommended more than $150 \mathrm{~m}$ \\
\hline Inclination of lignite bed & Preferred horizontal seams or small angle \\
\hline Rock mass and surrounding rocks tectonics & $\begin{array}{l}\text { Preferred absence of cracks and big tectonic distur- } \\
\text { bances (faults) }\end{array}$ \\
\hline Lithology of overburden rocks & $\begin{array}{l}\text { Preferred grounds of small permeability (clays, silts, } \\
\text { muds) }\end{array}$ \\
\hline Water conditions & $\begin{array}{l}\text { Preferred beds laying below utility aquifers (minimal } \\
\text { assumed distance - 40 m), absence of main under- } \\
\text { ground water reservoirs in the vicinity of planned } \\
\text { installations }\end{array}$ \\
\hline Reserves volume & $\begin{array}{l}\text { - research installation; minima reserves of 75,000 - } \\
450,000 \text { tons of lignite, } \\
- \text { commercial installation; min. 3.5 million ton sof } \\
\text { lignite. }\end{array}$ \\
\hline Preliminary safety conditions & $\begin{array}{l}\text { Preferred absence of surface facilities, rivers, lakes, } \\
\text { protected areas }\end{array}$ \\
\hline
\end{tabular}

Under the shortage of information the method of underground gasification is regarded as equal alternative for open pit mining. However, it is not always reasoned.

Poland has quite big reserves of lignite. Thus all available and technically processed methods of its extraction should be used. It is also possible to use the PZW method as supplementary with relation to open pit mining on the same deposit or its part. Anyway the correctly elaborated technical design is necessary.

The method of lignite deposit evaluation if it qualifies for gasification, presented here, is only a preliminary one. Different engineering measures are possible to improve the gasification conditions resulting from geological and hydrogeological conditions. However, addi- tional engineering methods may be expensive thus the final decision about applying the gasification depends on the cost-effectiveness of the project. The latter will change in the course of time depending on costs, prices, technical progress etc. Each project requires complex economic evaluation in order to identify possible to obtain profits offered by this method.

In case of PZW installation the biggest impact on costs have drillings made to build the exploitation (air blow and syngas extraction) and drainage wells. Therefore the most productive is gasification of lignite beds having great thickness.

Therefore economic, technical, legal and social factors decide about PZW method implementation. 


\section{CONCLUSIONS}

Popularity of underground lignite gasification method consistently increases. It is a result of Clean Lignite Technologies development. Probably in Poland it will be implemented within several years, what is a consequence of its development in many countries. Operation of gasification systems for example in China (and other countries) in the commercial scale, gives a chance for constructing, in a short time, such installations also in Poland.

Implementation of this method requires meeting many legal conditions concerning mining, power energy and building operations. Extremely high expectations concern the environmental issues. Polish environmental standards are currently compatible wit European Union ones. The EU also controls observing them.
Mining activity subject the special requirements. Basing on to date experience concerning the preparation of underground gasification it may be concluded that:

1. Construction of commercial installation in Poland is possible within 6-8 years.

2. The conditions for PZW installation implementation are as follows:

- proceeding formal and legal action in cooperation with relevant authorities and elaboration of necessary regulations,

- finding the social acceptance for new method,

- training the technical staff for handling the gasification system,

- carrying our reasonable strategy of lignite deposit development (including their protection) with regard of environmental protection policy.

\section{REFERENCES}

1. Prefeasibility study for pilot installation using underground gasification of lignite deposit and project commercialization. 2010. KGHM CUPRUM - CBR, Wrocław (not published).

\section{ABOUT AUTHORS}

Jan Kudelko - professor, vice-president KGHM "CUPRUM" Ltd. Research and Development Centre.

Lanusz Nowak - manager New Energy Technologies Department KGHM "CUPRUM" Ltd. - Research and Development Centre. 